\title{
Predictors of Job Satisfaction among Government Employees in DKI Jakarta
}

\author{
Cisilia Prilestari ${ }^{1}$, Debora E. Purba ${ }^{2}$, and Dyah T. Indirasari ${ }^{3}$ \\ \{cisilia.prilestari@gmail.com¹, eflina@ui.ac.id²,dyahti@ui.ac.id ${ }^{3}$ \} \\ Faculty of Psychology Universitas Indonesia, Kampus UI Depok 16424 Jawa Barat Indonesia ${ }^{1,2,3}$
}

\begin{abstract}
This study aims to examine the role of occupational self-efficacy in the relationship between Future Time Perspective (FTP) and job satisfaction. Drawing on self-determination theory, we argue that employees with high levels of FTP tend to have high levels of occupational self-efficacy since they are determined to achieve their goals by enhancing their skills and abilities. This, in turn, will lead to high job satisfaction. The data were collected from civil servants at an Indonesian government organization $(N=$ 227) and were analyzed using Hayes' macro on SPSS. Results showed that FTP was positively and significantly associated with job satisfaction, and occupational selfefficacy partially mediated the relationship.
\end{abstract}

Keywords: future time perspective, job satisfaction, occupational self-efficacy, selfdetermination theory

\section{Introduction}

Since the bureaucratic reform in Indonesia was enacted in 1998, improving the quality of public services has become the government's priority to meet public expectations. Henceforth, public services can be improved by increasing employee job satisfaction[1]. Result of previous research showed that civil servants have low job satisfaction[2], and this may lead to poor public service quality. Therefore, it is imperative to increase civil servants' job satisfaction to increase public service quality. Job satisfaction is the attitude and description of what employees feel about their work[3]. The study of job satisfaction attracts a lot of organizational attention to this date because it can enhance organizational citizenship behavior[4],[5], organizational commitment[6], retention[6],[7], and productivity[8]. Job satisfaction has environmental and individual factors[9]. Environmental factors include superior-subordinate communication, pay, organizational climate and promotional opportunity. Individual factors include demographic characteristics such as age, sex and education[9], Future Time Perspective (FTP)[10], and occupational self-efficacy[11]. Thus, in the current study, we will focus particularly on FTP as the predictor of job satisfaction. To our knowledge, research on FTP has not widely discussed in the work context[12]. There are only a few studies relating FTP with job satisfaction[10],[13]. The studies showed that the correlation between FTP and job satisfaction is relatively low $(r=0.13-0.29)$. This low correlation coefficient indicates that there are other psychological mechanisms that mediate the relationship between FTP and job satisfaction.

FTP is one of the five dimensions of time perspective theory as proposed by Zimbardo and Boyd[14]. They divided time perspective variable into five dimensions, namely past 
positive (having attachment to a positive past), past negative (focusing on negative experience in the past), present fatalistic (perceiving present time with despair and helplessness), present hedonistic (having an orientation towards fun in the present time and are less interested in future consequences), and future. FTP is considered as a prominent characteristic in individuals and is powerful in influencing one's attitudes and behaviors in the workplace compared to the other time perspectives[15]. Individuals with high FTP are ambitious and reward dependent, and always plan and strive to achieve goals of high standards, tend to do something meaningful that inherently brings positive experiences like higher job satisfaction[10], even if they have to postpone today's fun[16].

We draw on self-determination theory[17] to explain the relationship between FTP and job satisfaction. Self-determination theory defined as the fulfillment of one's basic psychological needs, including the need for autonomy (desire to feel capable of managing one's own actions and behaviors), competence (ability to feel effective and to master challenges), and relatedness (desire to feel in relation with others). An individual with high FTP enjoys high autonomy in doing their work, feel competent, and socially bond with others, all of which help them achieve their goal, and in turn will lead to more positive outcomes, including higher satisfaction. We hypothesize the following:

Hypothesis 1: Future time perspective positively correlates with job satisfaction.

As we discussed previously, there are other mechanisms that can better mediate the relationship between FTP and job satisfaction. Again, we use self-determination theory to argue the mediating effect of occupational self-efficacy in the relationship between FTP and job satisfaction. Occupational self-efficacy refers to individual beliefs that one is capable of accomplishing tasks or job[11]. Individuals who have the occupational self-efficacy would have self-esteem, internal locus of control, mastery, and optimism to successfully fulfill the task involved in their job. Furthermore, past studies reported that occupational self-efficacy has relationship with job satisfaction because the feeling of being capable of doing the job results in positive emotions such as satisfaction with job aspects[11]. Individuals with high FTP see that goals are important and they need to improve their skills to achieve the goals[18]. These efforts lead them to have the confidence of performing their job well. Thus, using selfdetermination theory, it can be assumed that individuals with high FTP, capable of seeing their long-term goals, would tend to seek autonomy to reach their goal, feel competent and have the need to grow a social bond with others. In doing so, they enhance their beliefs that they are capable of doing their job, and in turn will be satisfied with various aspects of their job. Based on the above arguments we hypothesize that:

Hypothesis 2: Occupational self-efficacy mediates the relationship between future time perspective and job satisfaction.

\section{Method}

We conducted a cross-sectional study by collecting data using a self-report questionnaire. Data were collected from civil servants in government institutions in Jakarta, Indonesia, 329 questionnaires were distributed, of which 276 were returned (response rate $=83.89 \%$ ). We decided to leave out 49 data due to incomplete demographic information and extreme responses. Therefore, the final sample consisted of 227 participants; mean age was 37.56 years $(S D=8.15)$, and the number of female participants is $141(62.1 \%)$. A number of $35(15.4 \%)$ 
participants were high school graduates, 151 (66.5\%) were university graduates, and 41 $(18.1 \%)$ were postgraduate. FTP was measured using 13-item Zimbardo Time Perspective Inventory (ZTPI) developed by Zimbardo and Boyd[14] $(\alpha=.75)$; occupational self-efficacy was measured using 6-item Occupational Self-Efficacy Scale (OCCSEFF scale) $(\alpha=.80)$ developed by Schyns and von Collani[11]; and job satisfaction was measured using 9-item Job Satisfaction Survey (JSS) developed by Spector[3] $(\alpha=.81)$.

\section{Results and Discussion}

Table 1 shows the means, standard deviations and correlations between variables. FTP is positively and significantly correlated with occupational self-efficacy and job satisfaction $(r=$ $.47, p<.01 ; r=.37, p<.01$, respectively). Occupational self-efficacy positively and significantly correlated with job satisfaction $(r=.40, p<.01)$.

Table 1. Means, Standard Deviations, and Correlation Among Variables

\begin{tabular}{lcccccc}
\hline \multicolumn{1}{c}{ Variable } & $M$ & SD & 1 & 2 & 3 & 4 \\
\hline Age & 37.56 & 8.15 & & & & \\
Job Tenure & 11.93 & 7.97 & $.89 * *$ & & & \\
Future Time Perspective & 3.76 & .42 & -.04 & -.01 & & \\
Occupational Self Efficacy & 4.84 & .48 & -.05 & -.06 & $.47 * *$ & \\
Job satisfaction & 4.88 & .46 & $.14 *$ & .12 & $.37 * *$ & $.40 * *$ \\
\hline
\end{tabular}

Note. $\mathrm{N}=227$. Age and job tenure were measured in years. ${ }^{* *} \mathrm{p}<.01,{ }^{*} \mathrm{p}<.05$.

The hypotheses in this study were analyzed using the mediation analysis[19] of Hayes's PROCESS macro 2.16.3 on SPSS version 24. Hypothesis 1 states that FTP is positively related to job satisfaction. Table 2 showed that there is a positive and significant relationship between FTP and job satisfaction (total effect $=.41, S E=.07, p<.01$ ). Therefore, our data supported Hypothesis 1. Hypothesis 2 states that occupational self-efficacy mediates the relationship between FTP and job satisfaction. Results showed that the indirect relationship between FTP and job satisfaction is also significant (indirect effect $=.15, S E=.04,95 \% C I$ [.0710, .2454]). Therefore, our data also provided support for Hypothesis 2. However, occupational self-efficacy only partially mediated the relationship, because the direct effect of FTP on job satisfaction was still significant (direct effect $=.26, S E=.08, p<.05$ ).

Table 2. The Mediating Effects Occupational Self-Efficacy on The Relationship Between FTP and Job Satisfaction

\begin{tabular}{llccccc}
\hline & \multicolumn{6}{c}{ Outcome } \\
\hline Antecedent & $\begin{array}{c}M \text { (Occupational self- } \\
\text { efficacy) }\end{array}$ & \multicolumn{2}{c}{$Y$ (job satisfaction) } & \multicolumn{2}{c}{$Y$ (job satisfaction) } \\
& \multicolumn{1}{c}{$b(S E)$} & $p$ & $b(S E)$ & $P$ & $b(S E)$ & $P$ \\
\hline$X($ FTP) & $.53(.07)$ & $<.001$ & $.41(.07)$ & $<.001$ & $.26(.08)$ & .0007 \\
$M$ Occupational & - & - & & & $.28(.07)$ & $<.001$ \\
self-efficacy) & & & & & .20 & \\
$R^{2}$ & .22 & & .13 & & .07 & \\
$\Delta \mathrm{R}^{2}$ & - & & .09 & & \\
$F$ & 62.47 & $<0.001$ & 34.87 & $<.001$ & 28.05 & $<.001$ \\
\hline
\end{tabular}

Note. $\mathrm{N}=227$, indirect effect $=.15, S E=.04, p=.0002$ 
To the best of our knowledge, our study is one of the first to acknowledge the mediating effect of occupational self-efficacy in FTP-job satisfaction relationship. First, we found FTP to be positively and significantly related to job satisfaction, and the correlation coefficient is relatively stronger than reported by previous studies[10],[13]. We argue that our specific sample, i.e., civil servants, may have influenced the relationship. The reward systems in the public sector and private sector often differ in terms of compensation and benefits[20]. Work motivation for public sector employees lies in providing service to the public and in long-term employment. Therefore, public sector employees may have strong FTP that will influence their job satisfaction positively. In this regard, external factors of job satisfaction, such as pay, benefits, and recognition may not strongly drive public sector employees to pursue their goals. Conversely, they have an intrinsic motivation to pursue long-term plans and goals, particularly those related to public service motives, to fulfill their needs and satisfaction.

Second, our results also showed that there was an underlying psychological process that plays a part in the relationship between FTP and job satisfaction. Based on the selfdetermination theory, individuals with high FTP pursue their future goals, and in doing so they need high levels of autonomy, competence, and relatedness with others. Thus, having clear future goals leads individuals with high FTP to search for autonomy to do their job, the opportunity to enhance their skills and competencies and to develop meaningful relationships with others. In the process of satisfying the three basic psychological needs, they develop the belief that they are capable of doing their job (enhanced occupational self-efficacy), which in turn resulted in positive emotions in aspects of their job and ultimately leads to high job satisfaction. Finally, our finding showed that occupational self-efficacy only partially mediated the relationship between FTP and job satisfaction. This implies that there are variances of FTP that cannot be explained by occupational self-efficacy in relation to job satisfaction. Perhaps, variance regarding delayed gratification may explain an aspect of job satisfaction left unexplained by occupational self-efficacy[11],[14],[16]. Occupational selfefficacy explains about the employees confident feeling that they can complete their job even when they face challenging tasks but does not measure explicitly explain about delayed gratification. Employees may or may not delay their gratification when they put their confidence into action to complete their tasks depending on their levels of FTP.

As a practical implication, our results suggest that for employees with high FTP who are focused on achieving their objectives, organizations should align their goals with the organization's goals. Another practical implication for organization, FTP can be improved using an intervention program like training[16]. Organizations, through their human resources divisions, may design training programs to improve employees' perception about the future and encourage employees to develop themselves and their confidence in their ability to perform the job[18]. With this intervention program, employees can be expected to become more effective and satisfied with what they do so as to offer satisfactory performance in their work for the company[21]. FTP, occupational self-efficacy, and job satisfaction are all perceived by the individual, therefore self-report is the best method to collect the data. However, the self-report method is susceptible to social desirability bias, which refers to the tendency of respondents to respond to items more as a result of their social acceptability and appropriate manner than their true feelings. To reduce the effect, we assured anonymity and confidentiality at all times to ameliorate the social desirability response bias[10]. We suggest future research to employ a time series method in which variables are measured several times over some period of time to examine the variability of participants' responses[22]. In addition, the self-report method on all variables may also increase common method bias. We thus suggest that further research use the temporal separation method, in which data on predictors, 
mediators, and outcomes are measured separately over some period of time[22]. Another limitation of this study is that the sample used was rather homogeneous. Future research can attempt to replicate the present study in other populations, such as private sector employees or workers in different industries and professions, to see if the same results can be generalized.

\section{Conclusion}

This study found that occupational self-efficacy took the role of mediator on the relationship between FTP and job satisfaction. The findings contributed to the existing literature by showing that occupational self-efficacy plays the role of mediator in FTP-job satisfaction relationship and self-determination theory as a robust theory that can help explain the mediating effect of occupational self-efficacy. When the three basic psychological needs are satisfied they will have a belief that they are capable of doing their job and this results in positive emotions in aspects of their job that leads to high job satisfaction.

\section{Acknowledgement}

This work is supported by Hibah PITTA 2018 funded by DRPM Universitas Indonesia No. 2347/UN2.R3.1/HKP.05.00/2018

\section{References}

[1] J. Sunaryo, S., \& Suyono, "A test of model of the relationship between public service motivation, job satisfaction and organizational citizenship behavior," Rev. Integr. Bus. Econ., vol. 2, no. 1, pp. 384-398, 2013.

[2] A. Setianingsih, "Beban Kerja dan Motivasi terhadap Kepuasan Pegawai PNS dan Non-PNS," J. Ilmu Kesehat. Masy., vol. 6, no. 04, pp. 171-179, 2017.

[3] P. E. Spector, Job satisfaction: Application, assessment, causes, and consequences. California: Sage publications., 1997.

[4] A. Darmawati, L. N. Hidayati, and D. Herlina S, "Pengaruh kepuasan kerja dan komitmen organisasi terhadap organizational citizenship behavior," J. Ekon., vol. 9, no. 1, pp. 10-17, 2013.

[5] T. I. Sudarmo and U. D. A. Wibowo, "Pengaruh komitmen organisasional dan kepuasan kerja terhadap Organizational Citizenship Behavior (OCB)," Psycho Idea, vol. 16, no. 1, pp. 51-58, 2018.

[6] V. M. Widyadmono, "Pengaruh kepuasan kerja dan komitmen organisasi terhadap turnover intention (Studi pada Accounting Staff Perusahaan Swasta di DIY)," J. Manaj. Indones., vol. 15, no. 2, pp. 157-168, 2015.

[7] A. P. Prasetio, R. Mawaranti, and E. Martini, "Peran Stres Kerja dan Kepuasan Kerja Karyawan dalam Pengelolaan Tingkat Turnover Intention pada Karyawan Puskesmas Jasinga , Bogor," $J$. Manaj. Indones., vol. 18, no. 2, pp. 165-174, 2018.

[8] N. P. Nursiani, A. Thoyib, and A. Sudiro, "Karakteristik pembentuk motivasi kerja dan hubungannya dengan kepuasan kerja pegawai pada pemerintah kabupaten Badung-Bali.," WACANA, J. Sos. dan Humaniora, vol. 13, no. 3, pp. 503-514, 2010.

[9] S. E. Seashore and T. D. Taber, "Job Satisfaction Indicators and Their Correlates," Am. Behav. Sci., vol. 18, no. 3, pp. 333-368, 1975.

[10] D. A. C. Ortiz and M. A. Davis, "Future and past negative time perspective influences on job 
satisfaction and organizational commitment in Mexico and the United States," Manag. Res. J. Iberoam. Acad. Manag., vol. 14, no. 3, pp. 317-338, 2016.

[11] B. Schyns and G. von Collani, "A new occupational self-efficacy scale and its relation to personality constructs and organizational variables," Eur. J. Work Organ. Psychol., vol. 11, no. 2, pp. 219-241, 2002.

[12] H. Henry, H. Zacher, and D. Desmette, "Future time perspective in the work context: A systematic review of quantitative studies," Front. Psychol., vol. 8, no. 413, pp. 1-22, 2017.

[13] J. Korff, T. Biemann, and S. C. Voelpel, "Human resource management systems and work attitudes: The mediating role of future time perspective," J. Organ. Behav., vol. 38, no. 1, pp. 45-67, 2017.

[14] P. G. Zimbardo and J. N. Boyd, "Putting Time in Perspective: A Valid, Reliable IndividualDifferences Metric," J. Pers. Soc. Psychol., vol. 77, no. 6, pp. 1271-1288, 1999.

[15] P. Zimbardo and J. Boyd, The time paradox: The new psychology of time that will change your life. New York: Free Press, 2008.

[16] J. Qian, X. Lin, Z. R. Han, B. Tian, G. Z. Chen, and H. Wang, "The impact of future time orientation on employees' feedback-seeking behavior from supervisors and co-workers: The mediating role of psychological ownership," J. Manag. Organ., vol. 21, no. 3, pp. 1-14, 2015.

[17] E. L. Deci and R. M. Ryan, "The " What" and "Why " of Goal Pursuits : Human Needs and the Self-Determination of Behavior The "What' and "Why' of Goal Pursuits : Human Needs and the Self-Determination of Behavior," Psychol. Inq., vol. 11, no. 4, pp. 227-268, 2000.

[18] I. Park and H. Jung, "Relationships among future time perspective, career and organizational commitment, occupational self-efficacy, and turnover intention," Soc. Behav. Pers., vol. 43, no. 9, pp. 1547-1562, 2015.

[19] Andrew F. Hayes, Introduction to Mediation, Moderation, and Conditional Process Analysis: A Regression-Based Approach. New York: The Guilford Press, 2013.

[20] V. S. DeSantis and S. L. Durst, "Comparing job satisfaction among public-and private-sector employees.," Am. Rev. Public Adm., vol. 26, no. 3, pp. 327-343, 1996.

[21] T. A. Judge, C. J. Thoresen, J. E. Bono, and G. K. Patton, "The Job Satisfaction-Job Performance Relationship: A Qualitative and Quantitative Review," Psychol. Bull., vol. 127, no. 3, pp. 376407, 2001.

[22] P. M. Podsakoff, S. B. MacKenzie, J. Y. Lee, and N. P. Podsakoff, "Common Method Biases in Behavioral Research: A Critical Review of the Literature and Recommended Remedies," J. Appl. Psychol., vol. 88, no. 5, pp. 879-903, 2003. 